\title{
INFLUÊNCIAS NA QUALIDADE DA FORRAGEM DURANTE O ARMAZENAMENTO
}

\author{
BEZERRA, Janieire Dorlamis Cordeiro ${ }^{1}$ \\ SILVA, Natália Viana da ${ }^{2}$ \\ NASCIMENTO JÚNIOR, José Ribamar Silva do ${ }^{3}$ \\ CASTRO, Francisco Martins de ${ }^{4}$ \\ CARVALHO, Ana Paula Costa de ${ }^{5}$ \\ FRANÇA, Sánara Adrielle ${ }^{6}$ \\ BARBOSA, Steyce Neves ${ }^{7}$
}

\begin{abstract}
Recebido em: 2020.08.11 Aprovado em: 2020.09.23 $\quad$ ISSUE DOI: $10.3738 / 21751463.3829$
RESUMO: Na maior parte do mundo a criação pecuária é dependente da sazonalidade da produção de forragens. Desse modo, torna-se necessário garantir a disponibilidade do recurso forrageiro e a alternativa pode ser alcançada por meio da conservação. Para garantir uma conservação eficiente as etapas do processo de conservação, desde o corte até o armazenamento, devem ser bem elucidadas. A respiração da planta após o corte, o tipo e tamanho dos equipamentos, as instalações para o armazenamento e o clima durante o processo influenciam na qualidade desse alimento. Na comparação dos dois processos, o feno é o mais demorado, pois o material necessita ser desidratado até atingir uma umidade por volta de $20 \%$ e no processo de ensilagem o material é colhido com um teor de umidade entre 50 a $65 \%$. Objetiva-se com essa revisão discutir os fatores que influenciam a perda da qualidade da forragem durante a conservação na forma de feno e silagem, abordando as perdas causadas pela respiração das plantas, danos causados pela chuva, perdas ocasionadas pelos implementos agrícolas e perdas durante o armazenamento.
\end{abstract}

Palavras-chave: Conservação, Silagem, Feno, Perdas de MS

\section{INFLUENCES IN QUALITY OF FORAGE DURING STORAGE}

SUMMARY: Most of the world livestock breeding is dependent on the seasonality of production of fodder. Thus, it is necessary to ensure the availability of forage resource and the alternative can be achieved through conservation. To ensure efficient conservation stages of the conservation process, from cutting to the storage, must be well understood. The plant respiration after cutting, the type and size of equipment, facilities for the storage and the weather during the process influence the quality of that food. Comparing the two cases, the hay is the most time consuming because the material needs to be dried to achieve a humidity around $20 \%$ and silage process the material is harvested with a moisture content between 50-65\%. Objectively with this revision discuss the factors that influence the loss of forage quality during storage in the form of hay and silage, addressing the losses caused by respiration of plants, damage caused by rain, losses caused by agricultural implements and losses during storage.

Keywords: Conservation, Silage, Hay, DM losses

\footnotetext{
${ }^{1}$ ORCID iD https://orcid.org/0000-0002-2793-1273. Universidade Federal da Paraíba-UFPB

${ }^{2}$ Universidade Federal Rural de Pernambuco-UFRPE/Sede

${ }^{3}$ ORCID iD https://orcid.org/0000-0002-6150-5243 - Universidade Federal do Rio Grande do Norte/Escola

Agrícola de Jundiaí - UFRN/EAJ

${ }_{5}^{4}$ Escola Superior Batista do Amazonas-ESBAM

${ }^{5}$ Universidade do Estado do Amazonas - UEA

${ }^{6}$ ORCID iD https://orcid.org/0000-0002-3337-3597 Universidade Federal do Vale do São Francisco-UNIVASF

${ }^{7}$ Universidade Federal do Vale do São Francisco-UNIVASF
} 


\section{INTRODUÇÃO}

Na maior parte do mundo a criação pecuária é dependente da sazonalidade da produção de forragens, que muitas vezes ocorre em poucos meses do ano, como é o caso das regiões semiáridas. Desse modo, torna-se necessário garantir a disponibilidade do recurso forrageiro durante o ano e a alternativa pode ser alcançada por meio da conservação, a qual prima pela preservação do valor nutritivo da forragem com o mínimo de perda possível de matéria seca (MS) e energia.

Para garantir uma conservação eficiente tanto do ponto de vista nutricional como econômico, as etapas do processo de conservação, desde o corte até o armazenamento, devem ser bem elucidadas, principalmente quanto aos métodos utilizados: silagem e feno. Além disso, a respiração da planta após o corte, o tipo e tamanho dos equipamentos, as instalações para o armazenamento e o clima durante o processo influenciam na qualidade desse alimento. A separação física do material e as chuvas contribuem para maiores perdas de folhas, consequentemente, perda de nutrientes tais como os carboidratos solúveis, reduzindo no conteúdo de MS as frações digestíveis e aumentando a proporção das frações menos digestíveis. Sob o ponto de vista econômico, todas as perdas durante o processo de conservação devem ser contabilizadas, não somente a quantidade perdida, mas o efeito dessas perdas na concentração dos nutrientes e a resposta animal a esse alimento conservado.

Após o corte das forrageiras haverá mudanças em seu valor nutritivo, em maior ou menor grau, em virtude das ações químicas, físicas e biológicas que ocorrem, principalmente quando estas permanecem a campo. As perdas mais comuns estão relacionadas: ao corte, respiração, fermentação, lixiviação, menor proporção de folhas, mal recolhimento da forragem no campo, maior tempo de desidratação e o teor de umidade no momento do armazenamento. Com relação a ambientes, observa-se que em condições quentes e úmidas as perdas são maiores.

Na comparação dos dois processos, o feno é o mais demorado, pois o material necessita ser desidratado até atingir uma umidade por volta de $20 \%$, que será alcançado após 7 dias ou mais de secagem, o que dependerá do volume da leira. Assim, quanto mais fina for a leira menor será o tempo de secagem no campo. O feno poderá ser colhido com uma umidade próxima aos $28 \%$, contudo necessitará de mais cautela durante o processamento e armazenamento, uma vez que a má condução dos processos acarretará em perdas que varia de 15 a $100 \%$, sendo a faixa ideal entre 15 a $18 \%$. As chuvas ocorridas durante o processo de secagem condicionam a uma perda de aproximadamente $30 \%$, salientando ainda que etapa da colheita é a responsável pela maior parte das perdas ocorridas no processo de fenação. 
No processo de ensilagem o material é colhido com um teor de umidade entre 50 a $65 \%$, sendo armazenado nos silos entre 1 a 4 dias após o corte. As perdas no processo de ensilagem variam entre 14 a $24 \%$, onde a etapa de armazenamento é responsável por mais da metade das perdas ocorridas durante o processo.

Objetiva-se com essa revisão discutir os fatores que influenciam a perda da qualidade da forragem durante a conservação na forma de feno e silagem, abordando as perdas causadas pela respiração das plantas, danos causados pela chuva, perdas ocasionadas pelos implementos agrícolas e perdas durante o armazenamento.

\section{PERDAS POR RESPIRAÇÃO}

Imediatamente após o corte, iniciam-se as perdas de nutrientes, com alterações físicas, químicas e biológicas no material a ser armazenado devido aos processos de respiração celular e microbiológica, lixiviação e fermentação. Essas alterações segundo Reis e Moreira (2001) são inevitáveis, contudo, passíveis de serem minimizadas como, por exemplo, a remoção rápida de umidade do material vegetal que resulta na diminuição das perdas (Figura 1). O processo de secagem consiste de três fases que são descritas por Cândido et al. (2008):

$1^{\text {a }}$ Fase - Inicia-se após o corte, onde os estômatos permanecem abertos por até três horas. É uma fase é rápida e envolve intensa perda de água que varia de 10 a 30\%.

$2^{\mathrm{a}}$ Fase - Com o fechamento dos estômatos, a perda de água ocorre via cutícula, um processo mais lento no qual as perdas nessa fase ficam na faixa entre 10 a $15 \%$.

$3^{\mathrm{a}}$ Fase - A perda de umidade ocorre através da plasmólise celular, até atingir 15 a $20 \%$ de umidade. Essa é a fase mais crítica em que a planta é mais susceptível às condições climáticas, observando-se maiores perdas na qualidade do material quando há grandes oscilações climáticas, tornando as folhas mais quebradiças e o caule com alto teor de umidade.

Quanto maior o tempo de permanência do material a campo, maiores serão as chances de reidratação, prolongando a respiração celular e as atividades enzimáticas. 
Figura 1 - Curva de secagem de plantas forrageiras em condições ambientais uniformes.

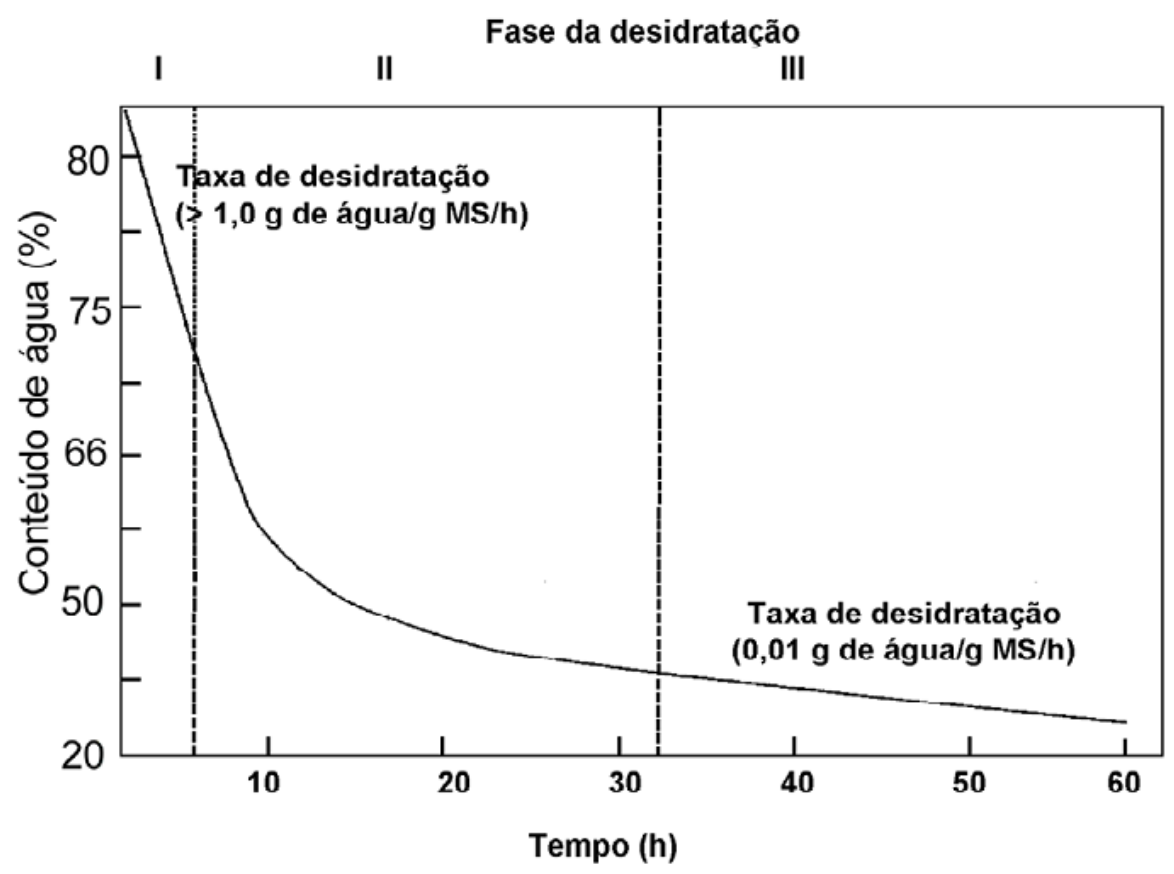

Fonte: Jones e Harris (1979), citados por Reis e Moreira (2001).

Após a colheita, as atividades metabólicas das células vegetais permanecerão ativas até que ocorra uma condição de letalidade. A respiração celular passa a diminuir a partir do momento em que o fornecimento de $\mathrm{O}_{2}$ e $\mathrm{H}_{2} \mathrm{O}$ diminui. A redução da respiração é quase proporcional à redução da umidade, cessando as atividades enzimáticas quando o teor de umidade varia entre 26 e 40\% (ROTZ; MUCK, 1994). A não interrupção das atividades enzimáticas, aliadas a uma reumidificação, prolongam a respiração. Além da respiração celular, a promovida por microrganismos também reduz a qualidade da forragem, por utilizar como substrato os carboidratos solúveis e, consequentemente, concentrar as frações menos digestíveis. Todavia, reforça-se que as perdas de MS pela respiração das plantas são maiores do que na respiração microbiana.

Os fatores que contribuem para o aumento da respiração celular são diversos e variam conforme a espécie a ser conservada e o aumento da temperatura, que eleva as taxas respiratórias, principalmente na faixa entre 30 a $40^{\circ} \mathrm{C}$ de forma exponencial até atingir um platô entre 40 e $50{ }^{\circ} \mathrm{C}$. A maturidade da planta influencia na taxa de respiração, quanto maior a maturidade menor serão as taxas de respiração em decorrência da menor demanda metabólica (TAIZ; ZEIGER, 2004).

As perdas de matéria seca e de nutrientes ocorrem devido ao déficit fotossintético, durante a respiração a glicose é oxidada, liberando energia e formando água e dióxido de carbono. Conforme Rotz e Muck (1994), após o corte a fotossíntese pode até ocorrer, mas por 
um curto período de tempo. A permanência da respiração acarreta em perdas de carboidratos solúveis, substratos importantes para o desenvolvimento dos lactobacilos, e aumenta as concentrações de PB, FDN, FDA e LIG, diminuindo a digestibilidade.

Normalmente, os carboidratos solúveis não são esgotados totalmente durante a respiração, mas caso isso ocorresse às plantas utilizariam vias glicólicas alternativas, utilizando outros compostos orgânicos como fonte de energia através da realização da gliconeogênese (TAIZ; ZEIGER, 2004). Conforme Muck e Shinnes (2001), a proteína bruta (PB) das forragens frescas é constituída de 20 a 30\% de NNP, de 60 a $70 \%$ de proteína verdadeira (PV) e de 4 a $15 \%$ de $\mathrm{N}$ indisponível (NIDA). As atividades proteolíticas resultam na produção de nitrogênio não proteico (NNP), consequentemente, ocorre a diminuição da solubilidade da proteína verdadeira. As enzimas proteolíticas reduzem a qualidade da forragem através da hidrólise das proteínas e o aumento do NNP tais como amônia, nitrato, nitrito, aminoácidos livres, aminas e peptídeos, dentre outros (REIS; MOREIRA; PEDREIRA, 2001).

\section{PERDAS CAUSADAS PELA CHUVA}

As chuvas contribuem em média cerca de $30 \%$ das perdas de MS no campo, podendo aumentar para mais de 50\% a depender da quantidade, intensidade e duração das chuvas, dos fatores inerentes à cultura e dos fatores ambientais (ROTZ; MUCK, 1994). A chuva interfere na conservação e na qualidade da forragem ao prolongar os processos celulares de respiração, na lixiviação de compostos solúveis (carboidratos, nitrogênio, mineral, lipídeos) e nas perdas de folhas, consequentemente, concentrando frações pouco digestíveis. As perdas pela chuva estão praticamente entrelaçadas com os efeitos de perda por respiração, ou seja, a quantificação individual das perdas por chuva e por respiração é praticamente impossível. Assim como na respiração, a lixiviação acarreta em perdas de compostos solúveis e aumenta as concentrações de FDN, FDA, PIDA e LIG, diminuindo a digestibilidade (JENNINGS, 2010).

Durante as chuvas os impactos das gotas de água aumentam as perdas de folhas, contudo a lixiviação de nutrientes solúveis, sem dúvidas, é o fator que mais contribui nas perdas. A intensidade das chuvas está mais relacionada com as perdas foliares e a quantidade e duração com as perdas por lixiviação dos nutrientes. Quando as chuvas ocorrem na fase final na secagem, momento onde as células estão mortas e a membrana mais fragilizada, os 
danos são maiores em comparação com as chuvas ocorridas no inicio do processo de secagem (REIS; MOREIRA; PEDREIRA, 2001).

As perdas de MS podem ser acentuadas devido aos fatores inerentes da cultura tais como: o conteúdo de umidade no momento em que ocorreram as chuvas, a maturidade, a relação F:C, a espécie forrageira, a densidade da massa no campo e do tratamento da forragem no momento do corte. Dentre os fatores supracitados, a umidade é o de maior efeito, pois as chuvas no inicio do processo de secagem provocam poucas perdas, todavia, à medida que a umidade da forragem diminui o efeito negativo da chuva será maior, ocorrendo diminuição da relação F:C e aumentando a lixiviação, no qual as perdas variam em função da espécie forrageira, contudo, independentemente da espécie haverá uma tendência de maior concentração de FDN (ROTZ; MUCK, 1994). As perdas causadas pelas chuvas possuem relação do teor de umidade da forragem, no qual quanto menor o teor de umidade e maior volume de chuvas, maiores serão as perdas (Figura 2).

Outros fatores que influenciam indiretamente são $o$ retardo da rebrota e o funcionamento das máquinas, ambos afetando na qualidade da forragem. Embora as perdas devido à maturidade e a espécies sejam pouco marcantes, estas influenciam na concentração e solubilidade do conteúdo celular, portanto, indiretamente nas perdas.

Figura 2 - Perdas induzidas por chuva em alfafa condicionada mecanicamente.

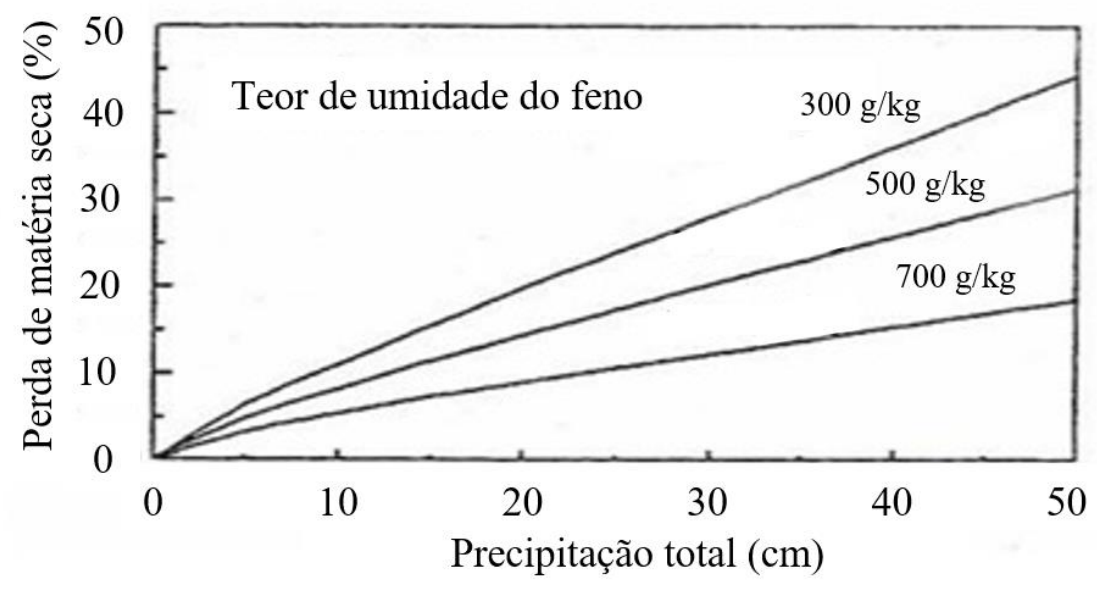

Fonte: Rotz e Muck (1994).

\section{PERDAS CAUSADAS PELOS EQUIPAMENTOS}

O uso de implementos agrícolas, do corte até a colheita do material, geram danos na qualidade e a contabilização das perdas varia de acordo com o tipo de máquina a ser utilizada, dos fatores culturais, da espécie cultivada, do estado de maturidade, do teor de umidade e da 
relação F:C. As perdas mais frequentes são de folhas, consequentemente, haverá uma diminuição da qualidade nutricional, visto que as folhas possuem uma maior concentração de nutrientes que são importantes na nutrição animal.

Fatores inerentes as plantas podem aumentar as perdas com a utilização dos equipamentos, como é o caso da umidade e da família forrageira (Poaceae ou Fabaceae). As leguminosas com teor de umidade abaixo de $30 \%$ são mais susceptíveis a perdas. Em forragens maduras as perdas podem dobrar em virtude da umidade mais baixa ou do enfraquecimento da ligação das folhas com as hastes (ROTZ; MUCK, 1994).

O corte pode ser realizado manualmente ou mecanicamente, utilizando-se de equipamentos como o alfanje ou roçadeira costal, a colhedora de forragens, a ceifadora/segadora (discos, barra ou tambor), com sistema condicionador ou não, salientando que a maioria dos equipamentos de condicionamento proporcionam melhorias na secagem. Outra perda com o maquinário é do material cortado no momento que sai do bico da colheitadeira para o vagão ou caminhão.

A maior pressão do rolo condicionador contribui para maiores perdas e os ancinhos rotativos aumentam as perdas principalmente quando o material está muito seco ou frágil. Para a correção das perdas nos ancinhos rotativos Boller (2012) sugere que a máquina seja operada com uma velocidade da tdp do trator abaixo de $540 \mathrm{rpm}$. Segundo Rotz e Muck (1994), as perdas de MS de uma roçada e um condicionamento variam de 1 a $5 \%$, de uma máquina de ceifa mangal entre 6 a 11\%, de uma maquina de inversão de faixa de 0 a 1,5\%. Os autores ainda atentam para a qualidade do material remanescente, o qual é negativamente afetado por esses processos pela grande perda de folhas.

Para acelerar a secagem no campo a alternativa é realizar a manipulação das faixas através de ceifadeiras, as quais utilizam os dentes giratórios para o revolvimento da forragem, fazendo com que a forragem que estava na parte inferior fique na parte superior e assim perca umidade. Ao espalhar o material em uma superfície mais ampla, há garantias de uma secagem mais rápida, contudo uma maior dificuldade para recolher o material e, consequentemente, as perdas serão maiores, principalmente em forragens com o conteúdo de umidade abaixo de 30\%. As perdas nesse processo, conforme Rotz e Muck (1994), variam entre 1 a 3\%, onde os mesmos relatam que o tipo de equipamento utilizado pode ser interessante em uma determinada espécie e em outra não. Nas gramíneas, por exemplo, é interessante a segadeira e nas leguminosas a ceifadeira. 
Quando o material é colhido na leira às perdas são de 1 a $3 \%$, a depender da estrutura das faixas, da espécie e do teor de umidade. No armazenamento do material na forma de fardos as perdas variam de 2 a $5 \%$, sendo maiores em fardos redondos, perdendo um conteúdo maior de folhas do que de hastes (ROTZ; MUCK, 1994). No Brasil, a preferência tem sido pela armazenagem de feno enfardado que, de acordo com Boller (2012), evita as perdas de folhas de forragens mais frágeis, diminui a exposição ao ambiente e reduz a necessidade de espaço para o armazenamento do feno.

Independentemente do tipo de técnica de conservação a ser adotado (ensilagem ou fenação), tem-se perdas durante a colheita e armazenamento (Figura 3) que podem ser minimizadas. Para a conservação em forma de silagem as maiores perdas são observadas durante o armazenamento, principalmente quando o teor de umidade é acima dos $70 \%$ e na forma de feno, as maiores perdas são observadas durante a colheita, sobretudo quando o teor de umidade é inferior a $20 \%$. Atenta-se ainda para o fato de que o feno com teor de umidade abaixo de $20 \%$ apresenta maiores perdas de MS quando comparados com silagem com teor de umidade próximo a $80 \%$.

Figura 3 - Estimativa das perdas de matéria seca durante a colheita e armazenamento de forragem conservada com diferentes teores de umidade na colheita.

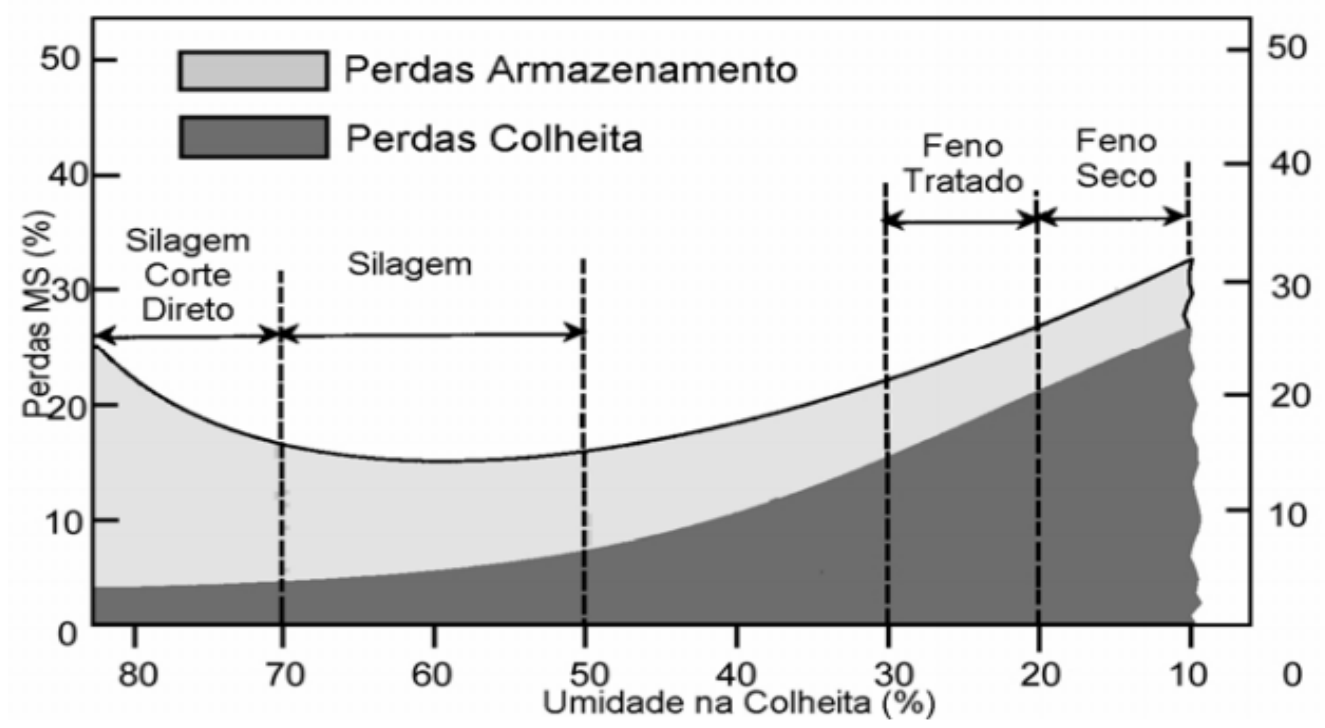

Fonte: Holland e Kezar (1990), citados por Ruggieri, Reis e Roth (2008).

Em estudo conduzido por Schogor et al. (2009), avaliando o efeito dos métodos de colheita sobre as perdas e os danos de colheita, observaram que as menores perdas durante o processo foram em torno de $17,7 \%$ no corte manual, contudo, quando observado o maior valor de perda em colmo obtido pelo método de colheita mecânica com rebaixamento manual, houve perdas de $25,7 \%$ em relação à produtividade (Tabela 1). 
Tabela 1 - Perdas de colheita das frações palha, folhas verdes e colmos remanescentes, em porcentagem da matéria seca em relação à produtividade colhida

\begin{tabular}{lcccccc}
\hline \multirow{2}{*}{ Variável } & \multicolumn{2}{c}{ Manual } & \multicolumn{2}{c}{ Mecanizado } & \multicolumn{2}{c}{ Mecanizado + rebaixamento anual } \\
\cline { 2 - 7 } & $\%$ & Erro-padrão & $\%$ & Erro-padrão & $\%$ & Erro-padrão \\
\hline Perdas totais & 17,7 & 3,66 & 18,4 & 1,83 & 25,7 & 1,83 \\
\hline Palha & 13,1 & 1,75 & 9,0 & 0,87 & 10,3 & 0,87 \\
Cana ponta & 3,2 & 0,9 & 2,9 & 0,45 & 4,1 & 0,45 \\
Colmos & $1,3 \mathrm{a}$ & 2,23 & $6,5 \mathrm{ab}$ & 1,11 & $11,3 \mathrm{~b}$ & 1,11 \\
\hline
\end{tabular}

Fonte: Schogor et al. (2009).

\section{PERDAS NO ARMAZENAMENTO DO FENO}

As perdas ocorridas no armazenamento do feno ocorrem devido à respiração de microrganismos, ou das plantas quando armazenadas com um teor de umidade superior do feno enfardado acima dos $20 \%$. Na respiração há a transformação da MS (especificamente de sacarose) em calor, água e gases, o que reduz a qualidade da forragem, já que os nutrientes mais digestíveis para o animal foram removidos. Vale salientar que quanto mais denso for o armazenamento dos fenos, maior será o aquecimento e quanto maior o tempo de armazenamento maior serão as perdas. As consequências do aquecimento é o aumento da fração de NIDA, PIDA e FDA, os quais ocorrem em virtude das reações de Maillard. As maiores mudanças do feno no período de armazenamento ocorrem quando o teor de umidade do material é acima de 30\% (ROTZ; MUCK, 1994; COBLENTZ; HOFFMAN, 2010; TAFFAREL et al., 2014).

As formas de armazenamento do feno são diversas, podendo armazenar ao ar livre ou em ambientes fechados, sendo que os fatores que afetam as perdas são diferentes nestas duas formas de armazenamento, dentre eles o fator intemperismo presente no armazenamento ao ar livre. Para o feno armazenado em ambientes fechados o principal fator que influencia nas perdas de MS é o teor de umidade. Em fenos com valores superiores a 30\% de umidade pode ocorrer perda excessiva de MS e combustão espontânea com perdas de MS por volta dos 8\%, já fenos com teor de umidade entre 15 e $18 \%$ são mais estáveis e a perda é em média de $1 \%$. (ROTZ; MUCK, 1994).

Com relação às perdas de nutrientes no período de armazenamento, nos primeiros meses ocorre grande perda de carboidratos, com o passar do tempo essas perdas se tornam menos acentuadas e as perdas em PB torna-se mais persistente, salientando que a digestibilidade da MS é cada vez menor com o aumento do período de armazenamento. Rotz e Muck (1994) relatam que essas perdas da PB são mais demoradas devido à lentidão da volatilização da 
amônia presente no feno ou proveniente da respiração microbiana, salientando que essas perdas independem da umidade.

Quando o armazenamento dos fenos ocorre ao ar livre, o tempo de armazenamento e a forma de armazenar possuem forte influência na qualidade do feno, bem como o clima da região. Em regiões de climas frios e secos e quentes e secos as perdas dos fenos são menores quando comparado a lugares onde a umidade é elevada. Outros fatores que podem afetar as perdas são a densidade dos fardos, orientação e o método de enfardar.

A exposição dos fardos no ambiente provoca muitas perdas nas regiões externas dos mesmos. A chuva, por exemplo, entra em contato com essa superfície reumidecendo-a, consequentemente, haverá uma elevação da atividade microbiana e perdas da qualidade. Uma alternativa para minimizar essas perdas seria o uso de uma lona ou um envoltório plástico.

A umidade final da desidratação, segundo Cândido et al. (2008), é responsável pelo êxito ou fracasso da fenação. A desidratação da forragem se processa até que a umidade do feno entre em equilíbrio com a umidade do ar (Tabela 2). Desse modo, fenos com teor de umidade abaixo em $20 \%$ em ambientes com umidade superior a $80 \%$, são susceptíveis a reumidificações, consequentemente, as células ficam cada vez mais fragilizadas aumentando as perdas e piorando a qualidade nutricional.

Tabela 2 - Relações entre umidade relativa do ar e a umidade de equilíbrio do feno

\begin{tabular}{cc}
\hline Umidade relativa do ar $(\%)$ & Umidade do feno $(\%)$ \\
\hline 95 & 35,0 \\
90 & 30,0 \\
80 & 21,5 \\
77 & 20,0 \\
70 & 16,0 \\
60 & 12,5 \\
\hline
\end{tabular}

Fonte: Raymond et al. (1991), citados por Cândido et al. (2008).

\section{PERDAS NO ARMAZENAMENTO DA SILAGEM}

O processo de ensilagem consiste no armazenamento de forragens mais úmidas em um ambiente com concentrações mínimas de $\mathrm{O}_{2}$, passíveis de serem consumidos nas primeiras horas após o fechamento do silo, para que ocorra fermentação e o desenvolvimento de microrganismos desejáveis, os quais preservam a qualidade da forragem com perdas mínimas de nutrientes, produzindo ácidos orgânicos como o lático, que garante estabilidade anaeróbica da silagem mais rapidamente e, consequentemente, minimiza as perdas. A respiração pode ser 
prolongada em função da alta umidade e alta concentração de $\mathrm{O}_{2}$, que poderá ser evitada por meio de um rápido enchimento do silo, boa compactação, vedação e adequado conteúdo de umidade. Os processos promovidos na ensilagem são dependentes da natureza, do tempo de ensilagem e das condições ambientais. Didaticamente, o processo de ensilagem é dividido em quatro fases: pré-fechamento, fermentação ativa, fase estável e abertura do silo (Figura 4).

A fase pré-fechamento (Figura 4) consiste do período do corte até a vedação do silo. Nessa fase a presença do $\mathrm{O}_{2}$ e a respiração podem interferir na qualidade da forragem, com perdas de massa seca e liberação de energia na forma de calor, aumentando a temperatura e podendo provocar reações de Maillard quanto esta ultrapassa $35^{\circ} \mathrm{C}$. Consequentemente, os aminoácidos e açúcares são polimerizados, aumentando as frações de NIDA e liberando mais calor (MCDONALD; HENDERSON; HERON, 1991).

As reações de Maillard, conforme Rotz e Muck (1994), são fortemente influenciados pela temperatura, podendo aumentar as frações de FDA e NIDA na silagem e diminuir a diferença entre FDN e FDA devido à complexação da hemicelulose. Quanto à umidade os autores afirmam que esta não afeta significativamente a reação de Maillard quando o teor de umidade da forragem encontra-se entre 40 a $70 \%$. Vale salientar que essa reação é responsável pelo superaquecimento, podendo ocorrer incêndios em silagens com teor de umidade abaixo de $45 \%$.

Figura 4 - Fases do processo de ensilagem.

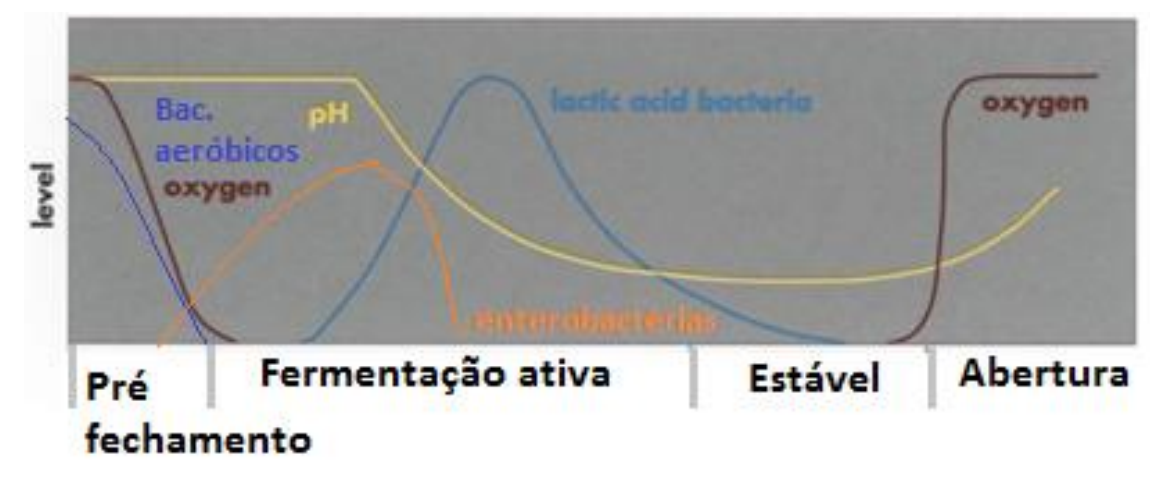

Fonte: Allen et al. (1995) (adaptado).

Após o corte, a respiração celular e de microrganismos é intensa porque as enzimas das plantas são liberadas devido à ruptura celular. Haverá quebra de proteínas em aminoácidos livres e peptídeos e dos carboidratos em açúcares fermentescíveis. Desse modo, haverá disponibilidade de substratos para o desenvolvimento de microrganismos aeróbicos como levedura e fungos e de anaeróbios facultativos tais como as bactérias ácido láticas e as enterobactérias (GUIM et al., 2002; PEREIRA; SANTOS, 2006). 
Quando o silo é vedado, o $\mathrm{O}_{2}$ é consumido rapidamente e o ambiente se torna anaeróbico, iniciando a fase de fermentação ativa e modificando a população de microrganismos (Figura 4 e Figura 5). Nessa fase, as células vegetais passam por lises liberando mais conteúdo celular. Bactérias como as enterobactérias e as BAL (bactérias ácido láticas), consomem esse substrato e produzem, dentre outros ácidos, o acético e o lático que contribuem no abaixamento do $\mathrm{pH}$ (principalmente o lático). Outros produtos podem ser produzidos por estes dois microrganismos, como etanol, 2,3-butanodiol, ácido succínico, ácido fórmico e manitol (Tabela 4).

Quanto mais rápido o $\mathrm{pH}$ da silagem baixar maior será a predominância dessas bactérias, sobretudo das BAL, que são inibidas pelo próprio ácido lático quando o $\mathrm{pH}$ está abaixo de 4, momento em que a silagem entra na fase de estabilidade. Já as enterobactérias, segundo grupo bacteriano mais numeroso da microflora epifítica e responsáveis pela maior produção de ácido acético e pela redução do nitrato $\left(\mathrm{NO}_{3}\right)$ a nitrito $\left(\mathrm{NO}_{2}\right)$ e óxido nitroso $\left(\mathrm{N}_{2} \mathrm{O}\right)$, são inibidas quando o $\mathrm{pH}$ fica abaixo de 5 (PEREIRA; SANTOS, 2006).

Figura 5 - Principais fases e atividades das plantas, microrganismos e processos químicos observados durante a ensilagem.

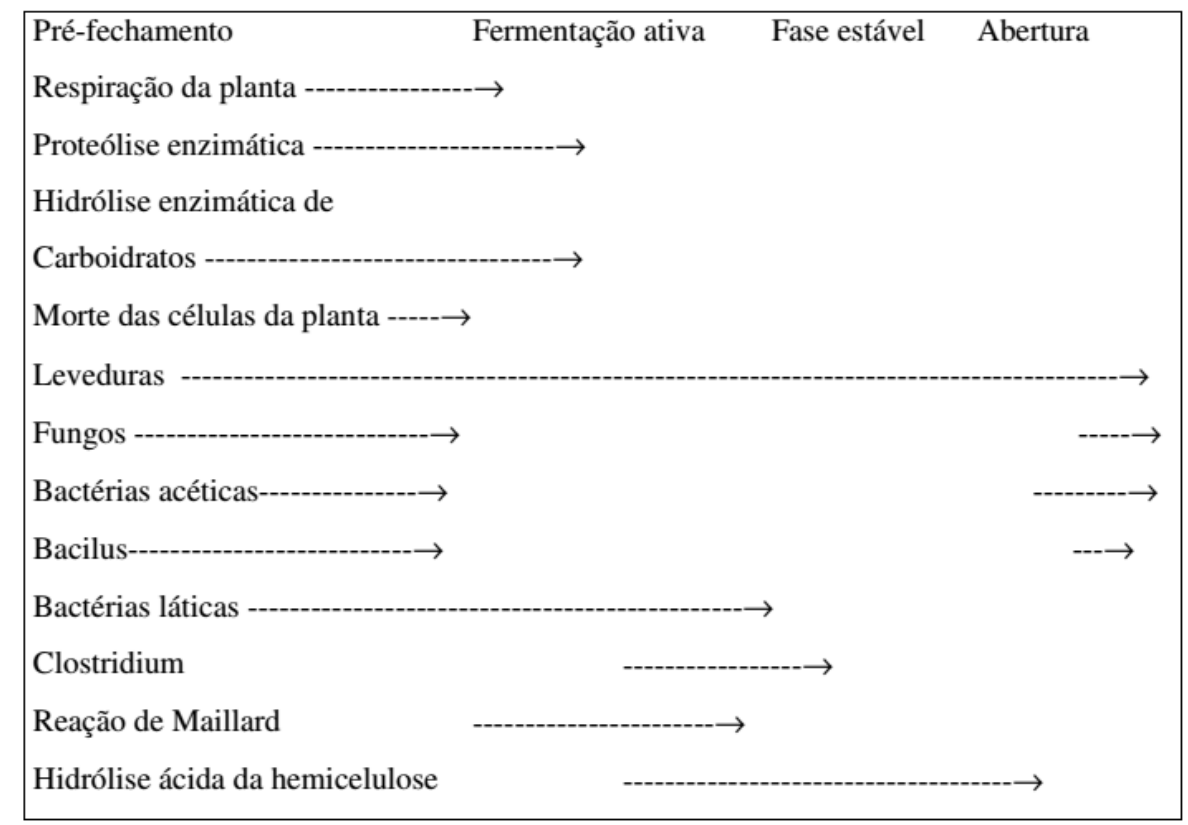

Fonte: Rotz e Muck (1994), adaptação de Reis e Moreira (2001).

A utilização de compostos solúveis pelas BAL produz mudanças menos adversas na qualidade da silagem, com poucas perdas de energia. Existem dois tipos de BAL as homofermentativas, que produzem somente o ácido lático e nenhuma perda de MS, e as heterofermentativas, que produzem ácido lático, etanol, $\mathrm{CO}_{2}$, ácido acético e manitol, resultam na perda de MS (Tabela 4). A quantidade de açúcar convertido pelas BAL é 
dependente da concentração dos açúcares, do teor de umidade e da capacidade tamponante, parando de crescer quando o $\mathrm{pH}$ está abaixo de 4 ou quando o substrato se esgota (MCDONALD; HENDERSON; HERON, 1991).

Outros microrganismos não são desejados como as bactérias do gênero Clostridium, leveduras, fungos, bactérias acéticas, bacilos, dentre outros. O gênero Clostridium atua em pH próximo a neutralidade (Tabela 3), sendo muito comum em situações onde a alta capacidade tampão do material ensilado impede o abaixamento do pH. Essas bactérias fermentam os açúcares, ácido lático e aminoácidos e produzem o ácido butírico e aminas com significativas perdas de MS (Tabela 4) e da palatabilidade. Os clostrídios, conforme Pereira e Santos (2006), podem ser divididos em três grupos: os fermentadores de ácido lático, os fermentadores de proteínas e aminoácidos e os que fermentam tanto proteínas e aminoácidos como ácido lático. A sua inibição na silagem pode ser realizada através do pré-murchamento e do rápido abaixamento do $\mathrm{pH}$.

$\mathrm{O}$ crescimento de leveduras irá ocorrer quando houver a presença de $\mathrm{O}_{2}$, ou seja, no préfechamento e na abertura do silo. Contudo, sua presença no silo é inevitável (Tabela 4), pois estas formam esporos e são resistentes ao abaixamento do $\mathrm{pH}$. A fermentação dos açúcares pelas leveduras causa perdas de MS devido à grande fermentação alcoólica.

Tabela 3- Características dos principais gêneros de bactérias presentes na silagem.

\begin{tabular}{|c|c|c|}
\hline Via & $\begin{array}{c}\text { Perda de matéria seca } \\
(\%)\end{array}$ & $\begin{array}{c}\text { Perda de energia } \\
(\%)\end{array}$ \\
\hline \multicolumn{3}{|l|}{ Bactéria ácido lática homofermentativa } \\
\hline 1 glicose $\rightarrow 2$ lactato & 0,0 & 0,7 \\
\hline 1 frutose $\rightarrow 2$ lactato & 0,0 & 0,7 \\
\hline \multicolumn{3}{|l|}{ Bactéria ácido lática heterofermentativa } \\
\hline $\begin{array}{l}1 \text { glicose } \rightarrow 1 \text { lactato }+1 \text { etanol }+\mathrm{CO}_{2} \\
3 \text { frutose } \rightarrow 1 \text { lactato }+3 \text { acetato }+2 \text { manitol }\end{array}$ & 24,0 & 1,7 \\
\hline$+1 \mathrm{CO}_{2}$ & 4,8 & 1,0 \\
\hline \multicolumn{3}{|l|}{ Clostrídios } \\
\hline 1 glicose $\rightarrow 1$ butirato $+2 \mathrm{CO}_{2}+2 \mathrm{H}_{2}$ & 51,1 & 20,9 \\
\hline 2 lactato $\rightarrow 1$ butirato $+2 \mathrm{CO}_{2}+2 \mathrm{H}_{2}$ & 51,1 & 18,4 \\
\hline \multicolumn{3}{|l|}{ Leveduras } \\
\hline 1 glicose $\rightarrow 2$ etanol $+2 \mathrm{CO}_{2}$ & 48,9 & 0,2 \\
\hline
\end{tabular}


Tabela 4 - Perdas de MS e energia da fermentação dos microrganismos.

\begin{tabular}{|c|c|c|c|c|}
\hline Gênero & Gram & pH final & $\begin{array}{l}\mathbf{T}^{\circ} \mathbf{C} \\
\text { ótima }\end{array}$ & Metabólitos \\
\hline Enterococcus & + & $4,2-4,6$ & 37 & Ácido lático \\
\hline Lactococcus & + & $4,2-4,6$ & 30 & Ácido lático \\
\hline Streptococcus & + & $4,0-4,6$ & 37 & Ácido lático \\
\hline Pediococcus & + & 4,2 & 37 & Ácido lático \\
\hline Leuconostoc & + & 4,8 & $20-30$ & Etanol, ácido lático, $\mathrm{CO}_{2}$ \\
\hline Lactobacillus homo & + & $4,0-4,5$ & 37 & Ácido lático \\
\hline Lactobacillus hetero & + & $4,0-4,5$ & 37 & Ácido lático, etanol, $\mathrm{CO}_{2}$ \\
\hline Clostidium & + & $6,0-7,0$ & $30-37$ & $\begin{array}{l}\text { Acetato, butirato, acetona e } \\
\text { isopropanol, } \mathrm{NH}_{3}\end{array}$ \\
\hline Listeria & + & 6,0 & $30-37$ & Ácido lático \\
\hline Enterobacter & - & 5,0 & 30 & $\begin{array}{l}\text { Butanediol, tri-metileno } \\
\text { glicol, } \mathrm{CO}_{2} \text {, acetato }\end{array}$ \\
\hline Bacillus & + & 5,0 & $30-37$ & Metabolitos da respiração \\
\hline
\end{tabular}

Fonte: McDonald, Henderson e Heron (1991).

A fase estável do armazenamento (Figura 4) inicia quando o pH está muito baixo ou quando não há substrato. Todavia, uma pequena atividade pode ocorrer nas regiões mais exteriores da silagem como a proliferação de mofo devido a uma pequena quantidade de $\mathrm{O}_{2}$ que ainda entra no interior do silo, por difusão via plástico ou até mesmo pelos concretos. Os mofos utilizarão como substratos os ácidos orgânicos (ácido lático) e o pH que outrora era baixo passa a se elevar, consequentemente, o ambiente dá condições para o desenvolvimento de outros microrganismos indesejáveis. As consequências nesse caso, além das perdas de MS, são de produção de micotoxinas prejudiciais à saúde animal. Segundo Jobim, Gonçalves e Santos (2001), os gêneros de fungos Fusarium, Aspergillus, Penicillium e Claviceps são responsáveis pela produção das micotoxinas mais preocupantes tais como Aflatoxinas, Desoxinivalenol, Zearalenona, Fumonisina e Toxina T-2, pois estas podem causar danos no fígado e rins, diminuir o desempenho reprodutivo, reduzir a produção de leite, saúde embrionária, desenvolver tumores, diminuir as funções imunológicas, causar edemas pulmonares e morte.

Dos fatores que afetam os processos de ensilagem, sem duvida a respiração da planta é uma das principais causas de perda de MS, juntamente com a respiração microbiana, ambos promovem proteólises e hidrólises. O nível de proteólise depende da idade da espécie, do $\mathrm{pH}$, da temperatura e do teor de umidade. A diminuição do $\mathrm{pH}$ para valores inferiores a 6 inibe a proteólise, contudo, não a elimina. A temperatura possui efeitos negativos, mas não 
acentuado, uma vez que o aumento da temperatura contribui para o aumento da atividade microbiana e com isso o pH tende a diminuir (ROTZ; MUCK, 1994).

Com relação às perdas da ensilagem pelos efluentes, há a ocorrência da lise celular da forrageira durante o armazenamento do silo, salientando que a quantidade de efluentes produzidos é dependente do teor de umidade da cultura e também do tipo de silo. Os efluentes são responsáveis pelo carreamento de compostos solúveis como os açúcares, proteínas solúveis e NNP e minerais como potássio cálcio fósforo e magnésio. Conforme McDonald, Henderson e Heron (1991), o teor de umidade do material ensilado onde não há perdas por efluentes varia entre 67 e $71 \%$. A produção de efluentes é maior durante a primeira semana de ensilagem e passa a declinar em seguida. Segundo Rotz e Muck (1994), o tipo de silo influência da seguinte forma, para cada $3 \mathrm{~m}$ de altura adicional para impedir a perda de efluentes o teor de umidade deve ser reduzido em 10\%. Isso se dá para minimizar a pressão ou a densidade elevada, que contribui para o aumento da produção de efluentes a um dado conteúdo de umidade.

$\mathrm{Na}$ fase de abertura do silo, o $\mathrm{O}_{2}$ penetra mais facilmente, contribuindo para $\mathrm{o}$ desenvolvimento de microrganismos aeróbicos responsáveis pela instabilidade após a abertura, por provocarem o aquecimento do material, reação de Maillard, perda de MS e baixa palatabilidade, além da produção de micotoxinas. Esses microrganismos, principalmente leveduras e bactéria de ácido acético, consomem os compostos açucarados e os produtos da fermentação. Os bacilos vão mais além utilizando as proteínas e alguns polissacarídeos e os mofos degradam uma ampla gama de substratos, inclusive carboidratos estruturais e lignina (MCDONALD; HENDERSON; HERON, 1991). O crescimento desses microrganismos é dependente do $\mathrm{pH}$, do substrato e do produto de fermentação (Tabela 3), por exemplo, as bactérias são mais sensíveis do que as leveduras quando o $\mathrm{pH}$ é inferior a 4 , os mofos possuem crescimento mais lento do que as leveduras e são sensíveis com a diminuição do $\mathrm{O}_{2}$, os bacilos são sensíveis em pH baixo e pelo produto da fermentação.

Quando a silagem é bem fermentada, o crescimento das leveduras e dos fungos é reduzido em virtude do efeito antifúngico do ácido acético não dissociado. Outros compostos também possuem ação semelhante, mas em menores intensidades, como os ácidos de cadeia curta, o ácido lático e o propiônico (MCDONALD; HENDERSON; HERON, 1991).

Estudiosos na conservação de forragem buscam quantificar todas as perdas durante o processo de conservação, todavia, existem etapas que são difíceis de avaliar. Mesmo 
utilizando modelos computacionais ainda não se tem uma forma eficiente de quantificar todas as perdas, mas algumas simulações norteiam os profissionais a preverem determinadas perdas.

\section{MÉTODOS PARA REDUZIR AS PERDAS E MELHORAR A QUALIDADE}

Várias opções para reduzir as perdas de MS e nutrientes durante a colheita e o armazenamento são utilizadas, incluindo modificações ou ajustes nos implementos e o uso de tratamentos químicos e biológicos os quais melhoram a secagem e o armazenamento, contudo, deve-se atentar para os custos adicionais com esses métodos, pois os mesmos podem se tornar inviáveis.

Os equipamentos para os processos de conservação foram, com o passar do tempo, aprimorados para atender os requisitos de preservação e qualidade da forragem. Dentre as evoluções se destacam as cortadoras e condicionadoras, que garantiram maior eficácia na secagem e minimização das perdas (ROTZ; MUCK, 1994). Os ajustes dos maquinários podem promover algumas melhorias, como uma movimentação mais suave do maquinário e um ajuste nas câmaras de enfardadeiras.

O uso de produtos químicos, tanto para gramíneas como para leguminosas, pode contribuir para uma secagem mais eficiente no campo. Estes produtos atuam induzindo a abertura dos estômatos ou modificando as cutículas antes do corte, todavia, esse tratamento não é muito prático. Dentre os produtos utilizados, pode-se citar carbonato de potássio ou de sódio e os herbicidas dissecantes como o dinoseb, endothal e diquat (REIS; MOREIRA; PEDREIRA, 2001).

O uso de aditivos na preservação do feno é interessante quando o teor de umidade do material é superior a $25 \%$. Os ácidos contribuem para a redução do crescimento de fungos, consequentemente, reduz as perdas. Os mais utilizados são os ácidos propriônicos, acético, fumárico, cítrico, benzóico, lático, fórmico e a mistura dos mesmos. Substâncias tamponantes (amoníaco) e inoculantes bacterianos também podem ser utilizados. Os ácidos propriônicos, por exemplo, promovem menores perdas da DIVMS, DIVFDN e níveis mais baixos de FDA, FDN e NIDA. Contudo a utilização de ácidos pode provocar corrosão em prensas e equipamentos, exceto quando tamponados. O uso do amoníaco anidro parece ser mais eficiente e econômico, impedindo o aquecimento e o desenvolvimento de fungos, além de aumentar a PB, a DIVMS e a digestão da hemicelulose e celulose, porém sua utilização é questionável devido a sua alta toxidade em animais e humanos. O uso rotineiro dos ácidos em fenos com alta umidade poderá ser inviável economicamente, principalmente, quando os seus 
efeitos benéficos são muito limitados, pois sua melhoria tem pouco efeito na perda de MS e na qualidade (MCDONALD; HENDERSON; HERON, 1991; ROTZ; MUCK, 1994; REIS; MOREIRA; PEDREIRA, 2001).

$\mathrm{Na}$ silagem os aditivos são utilizados amplamente, principalmente os inoculantes bacterianos, as enzimas e NNP. Os inoculantes bacterianos são os mais utilizados e promovem uma fermentação que resulta em grade produção de ácido lático, com o pH próximo a 4 e menores perdas MS, bem como redução na proteólise. Todavia, deve-se salientar que o sucesso do inoculante está relacionado com o tamanho da população de BAL natural. Segundo Pereira e Santos (2006) as bactérias ácido lático da microflora epifítica são essenciais para fermentação das silagens, seu crescimento na planta aumenta com a maturidade devido ao aumento do conteúdo de carboidratos solúveis e do teor de matéria seca. Salientam que o processo de picagem reativa as células dormentes e não culturáveis de BAL, aumentando sua população consideravelmente entre a colheita e a ensilagem.

Os aditivos enzimáticos consistem de uma mistura de celulase, hemicelulase, pectinase e amilase, que tem por finalidade reduzir o teor de fibra da silagem, reduzindo FDN e FDA. O uso desses aditivos promove uma maior eficiência no processo fermentativo, beneficiando a atuação de microrganismos BAL, disponibilizando açúcares simples como fonte de nutrientes para as bactérias. Essa prática pode promover maior disponibilidade de compostos fermentáveis que favorece a conservação e no rúmen a degradação e fermentação da fibra.

A utilização de aditivos químicos como a ureia, benzoato de sódio e hidróxido de sódio, são utilizados com o intuito de melhorar a fermentação durante a ensilagem. O uso de amônia e de ureia aumenta o teor de PB, melhora a MS e a digestibilidade da fibra e garante maior estabilidade da silagem, por contribuir no aumento da produção de ácido acético e proporciona menores perdas de MS. Entretanto, alguns aditivos possuem restrições devido ao perigo de contaminação ambiental (SANTOS et al., 2010).

Com relação ao desempenho animal, os trabalhos demostram que o ganho no animal é pouco significativo. Em estudo conduzido por Pedroso et al. (2010), avaliando três tipos de ração: $\mathrm{S} 1=$ ração com silagem tratada com ureia $(5,0 \mathrm{~g} / \mathrm{kg}$ de forragem fresca - FF) + benzoato de sódio $(0,5 \mathrm{~g} / \mathrm{kg} \mathrm{FF}) ; \mathrm{S} 2=$ ração com silagem inoculada com Lactobacillus buchneri $\left(5 \times 10^{4}\right.$ ufc/g FF) e S3= ração com cana fresca, observaram que o tipo de silagem não afetou o consumo de matéria seca (CMS) e produção de leite, mas foram inferiores quando comparados com a cana in natura. O conteúdo de gordura foi maior no leite de vacas alimentadas com silagem inoculados com L. Buchneri comparado com o leite de vacas 
alimentadas cana fresca (Tabela 5). Sendo assim, silagem inoculada com L. buchneri pode ser afetada de forma positiva, todavia, os dados ainda são incertos, pois os custos de cada silagem incluindo as possíveis perdas não foram contabilizados.

Tabela 5 - Desempenho, lactação e composição do leite de vacas da raça Holandesa alimentados com dietas completas

\begin{tabular}{lcccc}
\hline Item & \multicolumn{3}{c}{ Ração mista total } & SE \\
\cline { 2 - 4 } & $\mathrm{S} 1$ & $\mathrm{~S} 2$ & $\mathrm{~S} 3$ & \\
\hline Consumo de matéria seca (kg/dia) & $18,62 \mathrm{~b}$ & $18,34 \mathrm{~b}$ & $21,44 \mathrm{a}$ & 0,29 \\
Leite (kg/dia) & $17,44 \mathrm{~b}$ & $17,67 \mathrm{~b}$ & $18,55 \mathrm{a}$ & 0,18 \\
Leite corrigido para gordura (kg/dia) & $16,92 \mathrm{~b}$ & $17,38 \mathrm{ab}$ & $17,89 \mathrm{a}$ & 1,7 \\
Eficiência alimentar (kg LCG/kg CMS) & $0,91 \mathrm{~b}$ & $0,95 \mathrm{a}$ & $0,83 \mathrm{c}$ & 0,01 \\
Gordura (g/kg) & $33,4 \mathrm{ab}$ & $33,8 \mathrm{a}$ & $32,5 \mathrm{~b}$ & 0,4 \\
Proteína bruta (g/kg) & $32,5 \mathrm{a}$ & $32,5 \mathrm{a}$ & $33,0 \mathrm{a}$ & 0,2 \\
Lactose $(\mathrm{g} / \mathrm{kg})$ & $44,7 \mathrm{a}$ & $44,4 \mathrm{ab}$ & $43,8 \mathrm{~b}$ & 0,3 \\
Sólidos totais $(\mathrm{g} / \mathrm{kg})$ & $120,5 \mathrm{a}$ & $121,0 \mathrm{a}$ & $119,6 \mathrm{a}$ & 0,8 \\
\hline
\end{tabular}

LCG= Leite corrigido para gordura; $\mathrm{CMS}=$ Consumo de matéria seca.

Fonte: Pedroso et al. (2010), adaptado.

\section{CONSIDERAÇÕES FINAIS}

Os processos de conservação de forragem, da colheita ao armazenamento, são importantes para os sistemas agropecuários em várias regiões do mundo, principalmente em lugares com sazonalidade na produção de volumosos. Contudo, deve-se atentar para as perdas ocorridas durante a conservação tanto de feno como de silagem, pois cada uma possui suas peculiaridades. As perdas com a silagem são maiores durante o armazenamento e as perdas do feno são maiores durante o corte. As perdas influenciam na qualidade e os processos que contribuem para o aumento dessas perdas são a respiração, danos da chuva e danos mecânicos e perdas de armazenamento, os quais podem remover os hidratos de carbono e porção das folhas, lixiviar nutrientes solúveis, dentre outros fatores. No campo, deve-se acelerar o processo de secagem, reduzindo o número de operações de máquina ou modificando-as e adaptando-as para a redução das perdas.

\section{REFERÊNCIAS}

ALLEN, M. et al. Corn silage production, management and feeding. American Society of Agronomy, p. 1-41,1995.

BOLLER, W. Máquinas para a colheita e conservação de forragens. In: Fontaneli, R.S.; Santos, R.S.; Santos, H.P. (Org.). Forrageiras para Integração Lavoura-Pecuária-Floresta na Região Sul-Brasileira. Passo Fundo: Embrapa Trigo, 2012. p. 367-434. 
CÂNDIDO, M.J.D. et al. Técnicas de fenação para a produção de leite. In: XII Seminário Nordestino de Pecuária - PECNORDESTE, 2008. p. 261-298.

COBLENTZ, W.K.; HOFFMAN, P.C. Effects of spontaneous heating on estimates of total digestible nutrients for alfafa-orchardgrass hays packaged in large round bales. Journal of Dairy Science, v. 93, n. 7, p. 3377-3389, 2010.

GUIM, A. et al. Estabilidade aeróbica de silagens de capim-elefante (Pennisetum purpureum, Schum) emurchecido e tratado com inoculante microbiano. Revista Brasileira de Zootecnia. v. 31, n. 6, p. 2176-2185, 2002.

JENNINGS, J.A. Rainfall effects on wilting forages. University of Arkansas, United States Department of Agriculture and County Governments Cooperating. Agriculture and Natural Resources, Univ. Arkansas, Div. Agric., 2010. 8 p.

JOBIM, C.C.; GONÇALVES, G.D.; SANTOS, G.T. Qualidade sanitária de grãos e de forragens conservadas "versus" desempenho animal e qualidade de seus produtos. In: Jobim, C.C.; Cecato, U.; Damasceno, J.C.; Santos, G.T. (Org.), Simpósio Sobre Produção e Utilização de Forragens Conservadas, Maringá, v. 1, 2001. p. 242-261.

MCDONALD, P.; HENDERSON, A.R.; HERON, S. The biochemistry of silage. 2. ed. Marlow: Chalcombe Publications, 1991. 340 p.

MUCK, R.E.; SHINNES, K.J. Conserved forages (silage and hay): Progress and priorities. In: XIX International Grassland Congress, São Pedro, SP, Proceedings... Piracicaba: Brazilian Society of Animal Husbandry, 2001. p. 753-762.

PEDROSO, A.D.F. et al. Performance of dairy cows fed rations produced with sugarcane silages treated with additives or fresh sugarcane. Revista Brasileira de Zootecnia, v. 39, n. 9, p. 1889-1893, 2010.

PEREIRA, O.G.; SANTOS, E.M. Microbiologia e o processo de fermentação em silagens. In: Simpósio Sobre Manejo Estratégico da Pastagem, 2006, Viçosa, MG. Anais... Viçosa, MG: UFV, v. 3, 2006. p. 393-430.

REIS, R.A.; MOREIRA, A.L. Conservação de forragem como estratégia para otimização o manejo das pastagens. In: Congresso Brasileiro de Zootecnia XXI, 2001, Goiânia. Anais... Congresso Brasileiro de Zootecnia XXI. Goiânia: Universidade Católica de Goiás, 2001. p. 194-213.

REIS, R.A.; MOREIRA, A.L.; PEDREIRA, M.S. Técnicas para produção e conservação de fenos de forrageiras de alta qualidade. In: Simpósio Sobre Produção e Utilização de Forragens Conservadas. Anais... Marigá-PR, v. 1, 2001. p. 1-39.

ROTZ, C.A.; MUCK, R.E. Changes in forage quality during harvest and storage. In: Fahey Jr, G.C. Forage quality, evaluation, and utilization. Madison. American Society of Agronomy. p. 828-868, 1994. 
RUGGIERI, A.C.; REIS, R.A.; ROTH, A.P.T.P. Conservação da forragem de alfafa. In: Ferreira, R.P.; Rassini, J.B.; Rodrigues, A.A.; Freitas, A.R.; Camargo, A.C.; Mendonça, F.C. (Org.), Cultivo e Utilização de Alfafa nos Trópicos. Brasília: EMBRAPA, v. 1, 2008. p. 303-344.

SANTOS, E.M.; PINHO, R.M.A.; BEZERRA, H.F.C. Avaliação microbiológica de silagens. In: Rodrigues, R.C; Parente, M.O.M. (Org.). Simprupasto: o uso da ciência e de tecnologias para a mudança de paradigmas, Chapadinha: Edufma, 2012. p. 91-127.

SANTOS, M.V.F. et al. Fatores que afetam o valor nutritivo das silagens de forrageiras tropicais. Archivos de Zootecnia, v. 59, p. 25-43, 2010.

SCHOGOR, A.L.B. et al. Perdas das frações de cana-de-açúcar submetida a diversos métodos de colheita. Revista Brasileira de Zootecnia, v. 38, n. 8, p. 1443-1450, 2009.

TAFFAREL, L.E. et al. Produção de matéria seca e valor nutritivo do feno do tifton 85 adubado com nitrogênio e colhido com 35 dias. Revista Brasileira de Saúde e Produção Animal, Salvador, v. 15, n. 3, p. 544-560, 2014.

TAIZ, L.; ZEIGER, E. Fisiologia vegetal. 2. ed. Porto Alegre: Artmed, 2004. 719 p. 